\title{
Recurrent Intussusception in Adolescence: A Rare Entity
}

\section{Invaginação Recorrente na Adolescência: Uma Entidade Rara}

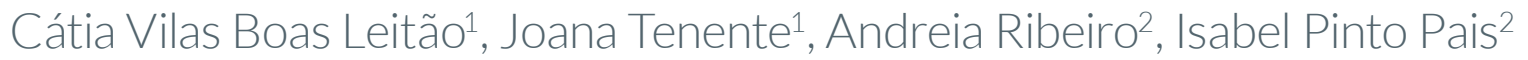

KEYWORDS: Adolescent; Intussusception

PALAVRAS-CHAVE: Adolescente; Invaginação Intestinal

A healthy 16-year-old male presented to the emergency department with vomiting and pain in the right iliac fossa for the previous 12 hours, with no other symptoms. On the physical examination the patient had pain in the right iliac fossa and localized rebound tenderness. An abdominal ultrasound showed a small bowel intussusception with approximately $4.9 \mathrm{~cm}$. Blood tests were normal, stool cultures and virology were negative. The intussusception reduced spontaneously in 24 hours.

One week later the patient had the same complaints and a new abdominal ultrasound confirmed the recurrence of the intussusception (Fig. 1). The abdominal and pelvic computed tomography scan showed no other alterations. The intussusception reduced spontaneously. The investigation was negative for intestinal parasitosis, celiac disease and ectopic gastric mucosa. A video capsule endoscopy revealed small nodules in the distal ileum related to lymphoid hyperplasia (Fig. 2). After 2 years of follow-up, there were no signs of recurrence.

Intussusception is a common cause of intestinal obstruction in infants and children. ${ }^{1-3}$ In older children, especially adolescents, it is less frequent and has an atypical presentation in most cases. ${ }^{1,2}$ Although the majority of pediatric cases are idiopathic, in 25\% a pathological lead point (PLP) can be determined, such as Meckel's diverticulum, intestinal duplication, lymphoid hyperplasia, intestinal polyps, vascular malformations or malignancies. ${ }^{1,4}$ Clinical suspicion is extremely important at every age, since the delayed diagnosis may lead to intestinal ischemia, perforation and peritonitis. ${ }^{1,3}$ 


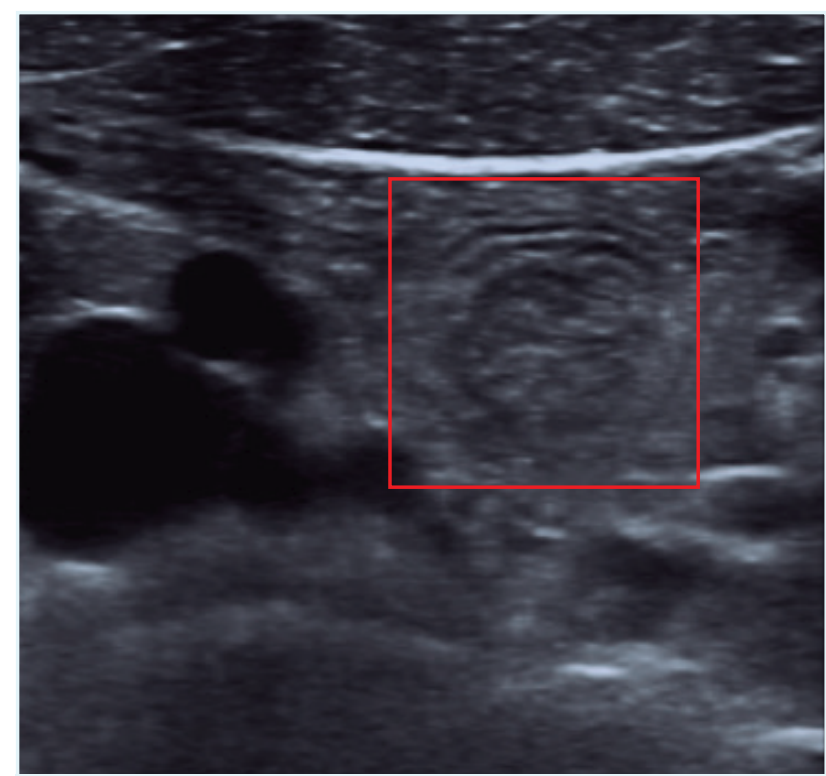

FIGURE 1. Ultrassound transverse image of a target shaped lesion, in the right iliac fossa, classical described as the "doughnut" or "target" sign, corresponding to the concentric rings of bowel wall (inside the red square).

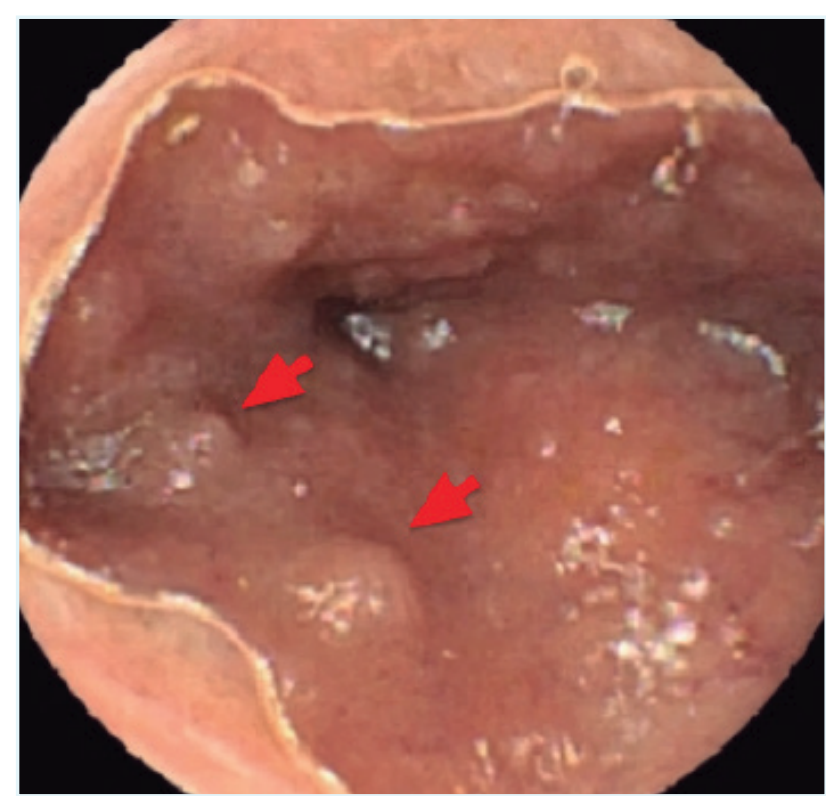

FIGURE 2. Video capsule endoscopy image showing small mucosa nodules (red arrows) in the terminal ileum, suggestive of nodular Iymphoid hyperplasia.

Recurrent intussusception occurs in approximately $10 \%$ of the cases. The risk factors have not been clearly defined, but older age (>1-2 years), absence of vomiting and PLP can be predictors of recurrent intussusception. ${ }^{3,5}$

Intestinal lymphoid hyperplasia is a benign condition and may act as a PLP for intussusception. ${ }^{4}$ A course of oral steroids may be used in cases of multiple recurrences; however, this approach needs more studies to be recommended. ${ }^{6}$
CONFLITOS DE INTERESSE: Os autores declaram não ter qualquer conflito de interesse na realização do presente trabalho.

FONTES DE FINANCIAMENTO: Não houve qualquer fonte de financiamento na realização do presente trabalho.

CONFIDENCIALIDADE DOS DADOS: Os autores declaram ter seguido os protocolos da sua instituição acerca da publicação dos dados de doentes.

CONSENTIMENTO: Consentimento do doente para publicação obtido.

PROVENIÊNCIA E REVISÃO POR PARES: Não comissionado; revisão externa por pares.

CONFLICTS OF INTEREST: The authors declare that they have no conflicts of interest.

FINANCIAL SUPPORT: This work has not received any contribution, grant or scholarship.

CONFIDENTIALITY OF DATA: The authors declare that they have followed the protocols of their work center on the publication of data from patients.

PATIENT CONSENT: Consent for publication was obtained.

PROVENANCE AND PEER REVIEW: Not commissioned; externally peer reviewed.

\section{REFERENCES}

1. Marsicovetere P, Ivatury SJ, White B, Holubar S. Intestinal intussusception: etiology, diagnosis, and treatment. Clin Colon Rectal Surg. 2017; 30: 30-9. doi: 10.1055/s-0036-1593429.

2. Mandeville K, Chien M, Willyerd F, Mandell G, Hostetler M, Bulloc B. Intussusception: clinical presentations and imaging characteristics. Pediatr Emerg Care. 2012; 28: 842-4.

3. Guo W, Hu Z,Tan Y, Wang J. Risk factors for recurrent intussusception in children: a retrospective cohort study. BMJ Open 2017;7:e018604. doi:10.1136/ bmjopen-2017-018604.

4. Ntoulia A, Tharakan SJ, Reid JR, Mahboubi S. Failed intussusception reduction in children: correlation between radiologic, surgical, and pathologic findings. AJR Am J Roentgenol. 2016;207:424.

5. Ye X, Tang R, Chen S, Lin Z and Zhu J. Risk Factors for Recurrent Intussusception in Children: A Systematic Review and Meta-Analysis. Front. Pediatr. 2019; 7:145. doi: 10.3389/ fped.2019.00145.

6. Gluckman S, Karpelowsky J, Webster AC, McGee RG. Management for intussusception in children. Cochrane Database Syst Rev. 2017:6:CD006476. doi: 10.1002/14651858. CD006476.pub3. 